\title{
REALIZATION OF EXPERIENTIAL FUNCTION OF NATIONAL ANTHEM OF INDONESIA
}

\author{
SRI HERIYANI NASUTION
}

\author{
Amrin Saragih \\ Rahmad Husein
}

Linguistik Terapan Bahasa Inggris Universitas Negeri Medan

\begin{abstract}
This qualitative study is aimed to find the Realization of Experiential Fuction of National Anthem of Indonesia. It was conducted by applying documentary study. The data analysis for this research was the text of National Anthem of Indonesia. The data were collected by applying a documentary technique. The document was read and analyzed to find out the Experiential Function. The data were analyzed by some procedures: data condensation, data display and drawing conclusion. Every elements of experintial function in the song or National Anthem represents the purpose of the song because the experiential function functions to represent the experience. The researcher also found there are so many ellipsis word in the song. Where that element can be found or detected from the context. Ellipsis means what is something left of linguistic elements. The ellipsis use because song is the simple language.
\end{abstract}

Keywords: Experiential Function, National Anthem, Discourse, Text and Context

How to Cite: Nasution, Sri Heryani (2017).

Representation of Experiential Function of National Anthem of Indonesia. Jurnal Linguistik Terapan Pascasarjana Unimed, 14 (2): 162-171. 


\section{INTRODUCTION}

Language can be explored in written and oral language or not from functionall point of view. Metafunction work in the clause, sentence, phrase because metafunctions states that they simultaneously encoded three strands meanings, Experiential, Interpersonal and Textual (Halliday in Gerot and Wignell, 1994:22)

Metafunction are analysis of text and context function. Metafunction refers to the Systemic Functional Linguistics created by Halliday. Metafuntion mean that language is functional. Metafunction is defined as functions which should be fulfilled by human beings in using language. Halliday $(1994 ; 179)$ describes metafunction as three tyes of meaning within grammatical structure of clause. A clause is a unit in which three of different kinds are combined, namely ideatinoal or experiential (clause as representation), interpersonal (clause as an exchange), and textual (clause as a message). Text and context are two points of language that cannot be separated one and each other as systems to convey meaning. Further, Martin states that a text is best regarded as a semantic unit, Martin (1992; 35).

Text and context also can be found in a song because song also has meaning. There is meaning in text and meaning in context. There is a song that has deep meaning. The song is create based on experience. The song occupies a special position and honored by all the people. The song is always sung or played on any official state events, and also any foreign events that carry the name of the country.

National anthem origins songs a struggle which later became anthem and also referred to as functional music. By studying them one by one in each stanza by stanza rhyme national anthem Indonesia Raya, we will find the spirit of Loving Homeland high that is transmitted by W.R Supratman and all the heroes of the struggling for Indonesian independence which aspires to the establishment of government is sovereign, founding built and maintained by an Indonesian native, by the children of the motherland is ready to become a scout for his mother.

The researcher wants to analyze the text of Indonesian National Anthem by using Halliday's theory. The researcher wants to apply the Metafunction on the song. The song is National Anthem. But the researcher only focus on the Experiential function because the researcher onl want to see the purpose and the experience that want to shared by the writer from the song.

\section{RESEARCH METHODOLOGY}

Design is defined as a researcher's plan of how to proceed (Bogdan and Biklen,1982:58).A descriptive qualitative design was applied in this study. Descriptive design simply described what data shown or what was going on by counting the percentage what was set source of the data. Qualitative analysis was then applied to find out theoretically which one seemed to be the better text to convey meaning and system of meaning in National Anthem of Indonesia. 


\begin{tabular}{|lccc|}
\hline 1. & Senser & 1 & 0.61 \\
2. & Phenomenon & 1 & 0.61 \\
3. & Token & 16 & 9.82 \\
4. & Value & 16 & 9.82 \\
5. & Carrier & 26 & 15.95 \\
6. & Attributive & 26 & 15.95 \\
7. & Possesser & 4 & 2.45 \\
8. & Possessed & 4 & 2.45 \\
9. & Behaver & 3 & 1.84 \\
10. & Sayer & 33 & 20.25 \\
11. & Verbiage & 33 & 20.25 \\
\hline
\end{tabular}

Table 2 shows that the kinds of participants used in the text of National Anthem of Indonesia are determined by the process in the clause. There are 11 kinds of participants with different number. They are senser ( 1 clause), phenomenon (1 clause), token and value (16 clauses) carrier and attributive (26 clauses), possesser and possessed (4 clauses), behaver (3 clauses) and the last is sayer and verbiage (33 clauses).

Table 3 Description of Circumstances Number

\begin{tabular}{|lccc|}
\hline No & Circumstances & Number & Percentages \\
\hline 1. & Extent & 1 & 20 \\
2. & Location & 3 & 60 \\
3. & Manner & 0 & 0 \\
4. & Cause & 0 & 0 \\
5. & Contingency & 0 & 0 \\
6. & Role & 1 & 20 \\
7. & Matter & 0 & 0 \\
8. & Accompaniment & 0 & 0 \\
9. & Angle & 0 & 0 \\
\hline
\end{tabular}

In Table 3 there are three kind of circumstances that use in the text of National Anthem of Indonesia. They are location, role and extent. There are three clauses that used location circumstances, one clause that used role and one clause that used extent. So the dominant circumstance is location. 


\section{Mental Process}

Mental process is only realized in one clause. The clause is "[aku] menjaga ibu sejati". The clause is found from the third stanza in the song. The word of menjaga is as process. It is explaining about the process of sensing. If it is related to the history, Aku is keep his country by saving all of thing in the country, saving the pure name and other. All process used sense. The participant is automatically determined by the process. if the process is mental so the participant $\mathrm{I}$ is senser and the participant II is phenomenon.

\section{Relational Process}

Relational process is the dominant process that used in the text. Relational prosess is realized to the process of being (including having). It is involves of identifying something. It is also involve with the quality identification of something. For example, in the clause "Indonesia [adalah] tanah air dan tumpah darahku". Here "adalah" is the process of relational: Possession. The clause is describing about the position of the Indonesia. Every human has homeland each other. It is Indonesia. The position of Indonesia is as homeland and the place of every people in Indonesia to try, figth and work hard. The word adalah is as connection of the relation of Indonesia and tanah air dan tumpah darahku. The clause is the statement of confession about Indonesia is the land that she/he is bord, live, grow up and serve to the nation. So can be seen the position of her/his and Inonesia. The case is the same with the some other clauses like Indonesia [adalah] kebangsaanku, bangsa dan tanah airku, Indonesia [adalah] tanah pusaka and [Indonesia adalah] pusaka kita semuanya.

The next is relational: attribution process or process of identify identification. The process determine participant I as carrier and participant II as atrribute. The clause is Indonesia Raya [adalah] merdeka. The clause is taken from firs stanza and number 13. The word Indonesia as participant I, adalah as process and merdeka is participant II. In the clause, the process realizes as identifying of the independent of Indonesia. To tell that Indonesia is independent. Has the relation with the purpose of clause if is is seen from the history of Indonesia. This song is established as National anthem after the Indonesia is free from colonialism. In the other word is after Indonesia is Independent. There clause is repeated so many times in the all stanza. So, many clauses are the same in analysis.

The different clause with the same process (relational:attribution) is Indonesia [adalah] tanah yang mulia. The clause is different but the functions of the clause is the same. It is realize as identifying of the Indonesia is a noble land. The Indonesia has the relation with the word tanah yang mulia because the word is the attributive for Indonesia where Indonesia as carrier and adalah is as the 
process that related the two of participants. This clause is same with [Indonesia adalah] tanah kita yang kaya. The two of clauses is taken from second stanza.

The last is relational: identification process. the process realized as identifying something and the quality of something. This process use the participant I as token and the participant II as value. Like in the clause "[Indonesia Raya adalah] tanahku yang kucinta" and [Indonesia Raya adalah] negeriku yang kucinta. The clause is talking about how is the value of Indonesia Raya that showed by the process adalah. The process identify the quality of Indonesia. It is the beloved land and country for the Indonesian people. The clauses can be found in every stanza in repeat in some times.

There other clauses in the same process are Indonesia "[adalah] tanah yang suci", [Indonesia adalah] tanah kita yang sakti, Indonesia [adalah] tanah berseri, and [Indonesia adalah] tanah yang aku sayangi. The caluses also use relational:identification which adalah is as process that relalized as identifying the quality of Indonesia. it is, the sacred land, victorious land, radiand land and the adored land.

\section{Behavioral Process}

The next process is behavioral process. where the process is usually done in every day. They are partly like the material and partly like the mental. But in behavioral process, range names the behavioral enacted. There is only one participant for this process. It is called behaver. There are three clauses that use behavioral process with the same process. It is berdiri. They are Disanalah aku berdiri jadi pandu ibuku, Di sanalah aku berdiri untuk selama-lamanya, Di sanalah aku berdiri. The process in the clause realized of talking that he/she stay in the land of Indonesia. He/she becomes the guide or leader for all of people in the land. He/she is born in the land, grow up in the land and will always serve to the land wherever she/he is

\section{Verbal Proces}

The last is verbal process. The process is process of saying or signaling. The participant of this process are sayer and verbiage. The clause that use the process are Marilah kita berseru "Indonesia bersatu!", [Marilah kita berseru] hiduplah tanahku and [Marilah kita berseru] hiduplah negeriku, marilah berseru is the process, kita is the sayer and Indonesia bersatu, hiduplah tanahku and hiduplah negeriku are the verbiage or the verbalization that is said by the sayer. The process is done orally or spoken. So many clauses that used the word berseru in the song. It is realized to implant the consciousness to the people that Indonesia is unite, long live and the other. All verbal process is word marilah berseru in the song and there are many times is repeated in the all stanza. It is to tell that the 
Indonesian people have to increase their life and create the better live in have a country. By say [Marilah kita berseru] hiduplah tanahku will make the spirit alive.

\section{Circumstance}

Now is talking about circumstance. For the first is location. The circumstance is reached place or time. The clause that used circumstance location are Disanalah aku berdiri jadi pandu ibuku, Di sanalah aku berdiri, Disanalah aku berdiri untuk selama-lamanya. The three of circumstances use the same word, it is Disanalah. The word is talking about Indonesia where he/she is born, live and serve. In the other word, the circumstance is describing the place or location.

For the second circumstance is role. Role is reached the time that explain about what as. Like in the clause "Disanalah aku berdiri jadi pandu ibuku". The circumstance role is "jadi pandu ibuku". The circumstance explains that he/she become the guide for his/her motherland. There is only one circumstance role in the song.

The last circumstance is extent. The circumstance is reached the duration for how long. Like in the clause "Di sanalah aku berdiri untuk selama-lamanya". The circumstance explains the duration for how long he/she stand in the land. The duration is selama lamanya or forever.

There are so many ellipsis word in the song. Where that element can be found or detected from the context. It means that the context of the previous and after of language. Ellipsis contributes the semantic structure of the discourse. Ellipsis means what is something left of linguistic elements, Halliday \& Matthiessen (2004;316). Ellipsis is another cohesive device. It happens when, after a more specific mention, words are omitted when the phrase needs to be repeated. The ellipsis replaces the omitted word. Ellipsis give help to find what is left. Normally, the meaning what ellipsis give no far from the real meaning.

The ellipsis use because song is the simple language. Song only used to convey meaning, purpose and message. To make the sentences/lyric is short, easy to be sung, and well to be listened, so the song is created in many ellipsises. It will not relieve the meaning of the song.

The ellipsis words are marked by [...] like in the clauses Indonesia Raya [adalah] merdeka!, adalah is the ellipsis word. The next is the clause "[Marilah kita berseru] Hiduplah tanahku" words are ellipsis because the words are omitted the phrase. The case is the same with the clause [Indonesia Raya adalah] tanahku yang kucinta and all clauses that are marked with symbol [...]. The dominant ellipsis used in relational process. 
Different with the research done by Ahmad Amin, he analyse Chemistery Text and he found ellipsis. In this research also found the ellipsis but in this research is found more. It is be cause this reseach is analyse song. the characteristics of song is use the simple language. Song only used to convey meaning, purpose and message. To make the sentences/lyric is short, easy to be sung, and well to be listened, so the song is created in many ellipsis. It will not relieve the meaning of the song.

If it seen from the theory of linguistics side, Halliday explains that explain that language is structure to make three kinds of meaning simultaneously, namely, Experiential, Interpersonal and Textual meanings, Halliday (1985; 316).

Halliday \& Hasan define A text is any passage, spoken or written of whatever length that forms a unified whole or the smallest meaningful passage of social language. A text can also be defined as an actual use of language which is produce for a communicative purpose.

Saragih $(2008 ; 1)$ stated that Context consists of 'co' plus text, co means 'together with', 'accompany' or anything that goes with or is together with the text. So, in analyzing text and context, there is a structure which sets them together such linguistic and social context, both are joint in one study, that is systemic functional linguistics.

The theory supported the finding. The song is a text that is arranged by the clause or sentences. The song as a text that defined as an actual use of language which is produce for a communicative purpose. The purpose that produce by the text of song can be seen by the element that is used in the song. Is is analysed by the experintial function's structures. By analyse the experiential function, it will be found the context of the song where the context determines field (what topic is being talked about).

\section{CONCLUSIONS}

The realization of the experiential function in the text is seen based on the element that is used. The first is mental process. The clause is "[aku] menjagaibusejati". The word of menjaga is as Mental process. The process is realize as explanation about sensing. If it is related to the history, Aku is keep his country by saving all of thing in the country, saving the pure name and ather. Relational prosess realize as the process of being (including having). It is involves of identifying Indonesia. It is also involve with the quality identification of Indonesia. Also identifying the position of Indonesia. The next process is behavioral process. Where the process is usually done in every day. The process realize to convey that he/she stay in the land of Indonesia. He/she becomes the guide or leader for all of people in the land. He/she is born in the land, grow up in the land and will always serve to the land wherever she/he is. The last is verbal process. The process is realize as process of saying or 
signaling. It is to tell that the Indonesian people have to increase their life and create the better live in have a country. By say [Marilahkitaberseru] hiduplahtanahku will make the spirit alive. All of the processes determine the participant itself. Now is talking about circumstance. For the first is location. The circumstance is reached place or time. It the other word, the circumstance is realized to as reach of the land of Indonesia. For the second circumstance is role. Role is realized to reach the time that explain about what as. What as she/he is for Indonesia. The last circumstance is extent. The circumstance is realized to reach the duration for how long she /he is in Indonesia. In the new finding, there are so many ellipsis word in the song. Where that element can be found or detected from the context. Ellipsis means what is something left of linguistic elements. The ellipsis use because song is the simple language

\section{REFERENCES}

Bogdan and Biklen. 1982. Qualitative Research in Education, An Introductionto Theory and Method. Bostom: Allyn \& Bacon.

Getot, Gerot and Peter Wignell. 1994. Making Sense of Functional Grammar. Sydney: Tanya Stabler.

Halliday, M.A.K. 1994. AnI ntroductionto Functional Grammar Second Edition. London: Edward Arnold.

Halliday, M.A.K. and Christian Mattiessen. 2004. An Introduction to Functional Grammar Third Edition. London: Edward Arnold.

Halliday, M.A.K. and R. Hassan 1985.Language, Context and Text, Aspect of Language in a Social Semiotic Perspective. Cambridge: Deakin University Press.

Koussouhon, Leonard A. 2015. Ideational Metafunction in HelonHabila's Oil on Water : A reevaluation and redefinition of African Women's Personality and Identity Through Literature. IJALEL (International Journal of Applied Linguistics \& English Literature).Vol.4 no.5. pp. 
129-136.

Martin, J.R. 1992. English Text : System and Structure. Amsterdam: John Benjamins.

Miles, M., M Huberman, J. Saldana. 2014. Qualitative Data Analysis, A Methods Sourcebook. Amerika: Arizona State University.

Saragih, Amrin. 2008. Factual Writing (Unpublished Lecture Notes). Pasca Sarjana Unimed. 